\title{
Имунологични фактори в етиопатогенезата на рецидивиращия и ексудативен среден отит
}

\author{
Стефан Лолов \\ ИБИР - БАН
}

\section{Увод}

Различават се няколко взаимно свързани типа на възпаление на средното ухо, които понякога преминават един в друг и следва да се разглеждат като форми на едно и също заболяване (Paparella et al., 1990). Те са добре познати на клиницистите и е постигнат консенсус относно дефинирането им (Bluestone, 2004). Съществува относителна яснота и по отношение на етиопатогенезата и клиничната картина на острия среден отит. Преобладават характерните за острото възпаление на средното ухо оплаквания (болка, повишена температура, обща интоксикация), както и специфичните за средното ухо симптоми (спадане на слуха, евентуално оторея и/или усложнения от разположените в съседство анатомични структури от жизнено важно значение). При 80\% от засегнатите, предимно деца, възпалението се самоограничава за около 3 дни и по-късно напълно преминава без трайни последици.

Съвременната антимикробна терапия редуцира значително процента на интракраниалните усложнения при остьр среден отит, но честотата на възпалителните заболявания на средното ухо остава все още висока, като се наблюдават промени на типа патология. Зачестяват случаите на рецидивиращ остьр отит при «податливи на отит» (otitis prone - (Howie et al., 1975) - около 5\% от съвременните деца спадат към тази категория (Alho et al., 1991). Някои предразполагащи за това състояние фактори са добре известни, обясними и частично могат да бъдат избегнати: 
контакт с голям брой деца (в семейството или при посещаване на детско заведение), изкуствено хранене, алергична предиспозиция, пасивно тютюнопушене. Други популярни, но по-малко проучени, предразполагащи фактори са наследственост и имунопатогенетични механизми.

Персистиращият ексудативен среден отит е третата често срещана форма на остро възпаление на средното ухо. През последните години се наблюдава както увеличаване на честотата, така и на научно-експерименталните доказателства за участие на различни имунологични мехаизми в патогенезата и на този вариант.

\section{Рецидивиращ и ексудативен среден отит}

Почти всички деца прекарват няколко епизода на остро възпаление на средното ухо през своето индивидуално развитие, без това да е свързано със значими трайни последици. Като условна граница между „нормалната честота“ на острия среден отит и рецидивиращата форма се приема цифрата от три или повече епизода за шестмесечен период, или четири или повече епизода за 1 година, при пълна липса на данни за възпаление между отделните епизоди. Към дефиницията следва да се добави и една особена група - деца с епизод на остьр отит преди 6-месечна възраст или с два епизода на възпаление преди навършване на 12 месеца, особено ако сьществува анамнеза за фамилна предразположеност (Bluestone and Klein, 2001).

Обичайно след остър отит, със или без перфорация на тъпанчевата мембрана, кухината на средното ухо напълно се „освобождава“ от микроорганизми и започва да се вентилира през Евстахиевата тръба. Отново няма строга граница норма/патология, но сьгласно проучванията около 2 седмици след прекаран остьр отит се установява наличие на течност в кухината на средното ухо при $70 \%$ от децата. След около месец от началото на възпалението продължава да се наблюдава излив при $40 \%$ от децата, а при $10 \%$ персистира до три месеца след началото на инцидента (2004). При средния отит с излив ${ }^{1}$

1 Международно приетият термин е среден отит с излив - otitis media with effusion. Дидактично се подразделя на остър, подостър и хроничен. Използването на термина „с излив“ предполага, че се касае за „неперфоративен“ - в противен случай би следвало да говорим за оторея. Използвам термина „персистиращ отит“, за да означа по-съкратено хроничния среден отит с излив, който е най-често срещаната форма. До колкото се касае за възпаление, „изливът“ е ексудат и съот- липсват симптомите на остро възпаление, но последиците от продължителното присъствие на богата на ензими и фибрин течност в кухината на средното ухо са съществени.

Въпреки наличието на дефиниция, естеството на здравната система често затруднява точното „класифициране“" на даден пациент. Ето защо, когато се правят проучвания върху заболяването, е особено важно прецизно формулиране на критериите за избор. При някои генетични изследвания, като пациенти с доказан персистиращ или рекурентен среден отит, се приемат само близнаци, при които и двата индивида са претьрпели мотивирана тимпаностомия. При подобни проучвания е добре от проследяваната група да бъдат изключени всички индивиди със съпьтстваща патология, особено различните форми на дизморфизъм. Съответно най-удачно е индивидите от контролната група да са без обективни и анамнестични данни за ушни проблеми. Подобен подход („narrow-phenotype“ approach) силно ограничава броя на клиничните случаи, като болшинството пациенти попадат в групата на „неуточнено състояние“, но от друга страна, направените изводи са много по-категорични (Rice et al., 2001).

\section{Основни хипотези}

Съществуват няколко възможни хипотези за различното развитие на класическия бактериален остър среден отит, от една страна, и причините за чести рецидиви или персистиране. Сьгласно едно от популярните схващания, първопричината може да се търси в биологичните особености на причинителя. Вариантите са относително често срещан неспецифичен инфект, който поради особености в реактивността на макроорганизма демонстрира понижена вирулентност и евентуално формира биофилм. Друг вариант е присъствието на специфичен за средното ухо бактериален причинител, за какъвто се приема Alloicoccus otitidis. Възможно е да се касае за индивидуални генетични особености, проявяващи се в неадекватна естествена или придобита резистентност на макроорганизма. Накрая и най-вероятно - комбинация от горните фактори.

ветно може да се ползва и терминът „ексудативен отит“, като в този случай давността на състоянието не е конкретизирана. В средното ухо може да се наблюдава и ,трансудат“, но това е патология извън рамките на коментираните в тази статия. 


\section{Неспецифичен бактериален причинител - класически отопатогени}

Непосредствено след раждането епифаринксьт се колонизира с непатогенни микроорганизми - стрептококи ( $\alpha$-хемолитични и нехемолитични), представители на род Neisseria, дифтероиди. Вероятно поселяването с патогени се възпрепятства от нормалната микрофлора и от пасивния имунитет - доказано е, че нивото на секреторните IgA в майчината кърма е обратно пропорционално на колонизацията на епифаринкса с нетипизируем Haemophilus influenzae (Harabuchi et al., 1994a). Вероятно има значение и начинът на приемане на млякото - смята се, че естественото сучене е свързано със създаване на по-малко отрицателно налягане от храненето с биберон, имайки предвид, че отрицателното налягане в епифаринкса играе важна роля в етиопатогенезата на средния отит.

Горните факти предлагат две интересни решения за профилактика. Едното е използването на пробиотици за създаване на микробен антагонизъм в горните дихателни пътища като подобра алтернатива на тоталното унищожаване на флората, както патологична така и нормална, с антибиотици. Второто решение е имунизация на бременните като средство за изграждане на пасивен имунитет у новородените и предотвратяване на ранен остьр отит като предшественик на рецидивиращата форма (Prellner et al, 1984). Прецизното честотно разпределение на найчестите причинители на рецидивиращия и персистиращ среден отит варира между различните проучвания, но не се различава принципно от това при отделните микробиологични видове, причиняващи остьр среден отит. Водеща роля има Streptococcus pneumoniae и съответно конюгираната ваксина срещу този причинител първоначално дава обнадеждаващи, макар и не категорични резултати - около $7.8 \%$ редукция на пациентите с остьр среден отит и около 24-26\% намаляване на пациентите с рецидивиращата и персистиращите форми (Fireman et al., 2003). Според друго проучване значително (57\%) намалява честотата на заболяванията, причинени от включените във ваксината серотипове, като същевременно се увеличава честотата на заболяванията, предизвикани от невключените във ваксината серотипове (с 33\%), т.е. настьпва феномен, популярен като серотипно изместване. Ваксината, разработена срещу Haemophilus

\section{МБ оториноларингология

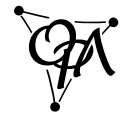

influenzae, е с още по-ниска ефективност, защото е създадена срещу типизируеми щамове, а чест причинител на остьр среден отит са нетипизируемите форми, като на Haemophilus influenzae тип В се дължат само 2-5\% от случаите (Reinert, 1997). За момента няма достьпна ефективна ваксина срещу Moraxella catarrhalis.

При рецидивиращата форма според едни автори всеки епизод се причинява от различен щам, като честотата на заболяването е правопропорционална на честотата на колонизиране на епифаринкса и зависи от ефективността на лигавичния имунитет (Harabuchi et al., 1994b). Според други проучвания $30 \%$ от рецидивите са резултат на един и същи щам (Leibovitz et al., 2003), което поставя под выпрос до каква степен „отрицателните“ култури вярно отразяват ситуацията.

\section{Лигавичен имунитет}

Секреторните имуноглобулини (sIgA) се свързват с разпознаваните от тях микроорганизми и блокират адхезията им към епителните клетки. С помощта на мукоцилиарния клирънс опсонизираните бактерии се отстраняват. В зоната на горните дихателни пътища, към която се отнася и средното ухо, превалира секрецията на $\operatorname{IgA1.~Може~да~се~предположи,~че~най-честите~}$ причинители на остър отит са тези микроорганизми, които поради биохимични особености най-ефективно се справят с лигавичната имунна система.

Някои синтезирани от бактериите извънклетьчни пептидази (IgA1-специфични ендопептидази) срязват тежката имуноглобулинова верига и отделят антигенсвързващия фрагмент (който остава прикрепен към бактериалната клетка и я скрива за действието на други интактни молекули антитяло) от Fc-фрагмента, отговорен за отключване на ефекторните механизми на макроорганизма. Щамове нетипизируем Haemophilus influenzae, предизвикващи клинично заболяване, имат по-висока експресия на ендопептидази от щамовете, изолирани от клинично здрави носители (Vitovski et al., 2002). Същият феномен е наблюдаван при инвазивни щамове Neisseria miningitidis.

\section{Имунологичен дефицит}

Имуноглобулиновите дефицити могат да бъдат генерализирани, но значително по-разпространени са „недостатьчностите“ на отделни под- 
класове. Бебета с ниски серумни IgG нива срещу капсуларните полизахариди на Str.pneumoniae типове 14 и 19F са по-склонни към ранно развитие на отит (Salazar et al., 1997). При деца с упорита оторея наличието на имуноглобулинов или клетъчен дефицит вероятно е по-скоро правило, отколкото изключение (Ovesen et al., 2011).

\section{Специфичен бактериален причинител}

Редица заболявания имат доказан специфичен причинител. Инфекцията с него почти винаги води до развитие на клинична картина и/или изграждане на имунитет, респективно борбата с причинителя силно ограничава или напълно ликвидира заболяването. Както вече отбелязахме, рецидивиращият и персистиращият среден отит преимуществено се предизвикват от три основни причинителя, но те са сравнително често срещани и не винаги водят до заболяване, а клинично проявената инфекция не винаги е свързана със засягане на средното ухо.

През 1989 г. в излива от средното ухо при деца с ексудативна форма среден отит е открит бавнорастящ грам-положителен микроорганизъм (Faden and Dryja, 1989), по-късно характеризиран като нов вид, сега означаван като Alloicoccus otitidis. Честотата на установяване на този микроорганизъм е съпоставима с тази на останалите три класически отопатогена, достига до $50 \%$ и силно зависи от изследваната популация, типизирането на пациентите и определяне на инфекта чрез култивиране или доказване с PCR. A.otitidis ce среща значително по-често при деца над 2-годишна възраст, изолира се и при остър среден отит (25\%), но бавният му растеж не позволява да се открие при класическо култивиране. Спорно е дали присъствието на A.otitidis при остър отит увеличава риска от преминаване на възпалението към ексудативна форма (Leskinen et al., 2004).

Присъствието на микроорганизъм в иначе стерилната среда на средното ухо не означава автоматично, че той участва в патогенезата на средния отит. Проучванията in vitro установяват, че A.otitidis стимулира продукцията на IL-8, IL-12, освобождаването на интерферон гама, експресията на CD 69 от Т- и В-клетки. Чрез Western blot в течността от средното ухо е доказано наличието на специфични антитела (IgM, sIgA, IgG2, (Harimaya et al., 2007) срещу този микроорганизъм. Установено е и че А. otitidis директно се свързва с Toll-like рецептор 2 , индуцирайки активацията на NF kappa-B (Konishi et al., 2006). Лансира се хипотезата, че горните механизми на стимулация на локална реакция, съчетани с продължително присъствие в средното ухо поради формирането на устойчив на антибиотици биофилм, са основното обяснение за персистиращо възпаление с изразена ексудация.

\section{Вирусен причинител}

Острият среден отит е най-често бактериално заболяване, но нерядко е последица на вирусна инфекция. Същото се отнася и за деца с рецидивиращ отит. Ето защо антивирусната ваксинация е индиректно средство за профилактика на отита. За момента се използва само противогрипна ваксина. В контролирани проучвания приложението иे намалява с $30 \%$ епизодите на остьр отит, но само по време на епидемия. Предполага се, че грипният вирус тип А подпомага адхезията на Str.pneumoniae към респираторния епител. Риновирусите инхибират ядрения транспорт и на тази база потискат естествената резистентност на дихателната лигавица към отопатогени.

\section{Алергичен модел}

Съгласно алергичния модел възпалението на лигавицата в зоната на Евстахиевите тръби е обусловено както от алергична реакция, така и от инфекция на горните дихателни пьтища, което е причина за неадекватна вентилация на средното ухо и създаване на отрицателно налягане в него. Този по-голям от обичайното градиент в налягането е причина при отваряне на тръбата да се аспирира в средното ухо секрет от епифаринкса, често с инфект и/или алергени. Аспирата попада в иначе стерилна кухина, често вече съдържаща трансудат, което е благоприятно условие за инфекция и/или локална алергична реакция.

До момента няма сигурни данни в подкрепа на това, че антиалергичната терапия, медикаментозна или специфична, има ефект върху честотата или тежестта на острия отит. Вероятността влошената функция на Евстахиевата тръба да е причина за рецидивираща форма на отит се опровергава и от наличието на пациенти с проведена тимпаностомия и последваща рецидивираща оторея. 


\section{Аденоидна вегетация}

И четирите основни бактериални причинителя на отит в детска възраст могат да бъдат изолирани от аденоидната тъкан, а според редица проучвания с повишена честота при деца с рецидивираща или персистираща форми на среден отит. Спорно е доколко именно третата сливица е „резервоар“ за инфекция, но несъмнено тази структура е силно ангажирана с изграждането на лигавичен имунитет (Karchev and Kabakchiev, 1984). Необоснованото провеждане на аденотомия като форма на хирургично лечение на рецидивиращ или персистиращ среден отит няма клинична стойност.

\section{Вроден имунитет}

Еволюционно консервативните структури на бактериалните клетки се разпознават от еволюционно консервативни рецептори при многоклетъчните организми и са в основата на т. нар. естествена резистентност. Поради факта, че в „здравото“ средно ухо няма флора, а броят на Т- и В-лимфоцитите е ограничен, се допуска поголямо значение на естествената резистентност (Ichimiya et al., 1990). При податливи на среден отит индивиди в наличната в средното ухо течност няма разлика в имуноглобулиновите концентрации, а в нивото на експресия на Toll-like рецептор 9. При същите индивиди се наблюдава и понижена експресия на цитозолните рецептори NOD-1 и NOD-2 (M. G. Kim и съавт. 2010), което е в противовес на наблюдаваната при остьр отит повишена експресия на Toll-like рецептор (Leichtle et al., 2009). Промените в естествената резистентност са предпоставка за дефицит и на придобитата резистентност като условие за възникване на рецидивиращ среден отит.

\section{Биофилм}

Възможно е проникналите в кухината на средното ухо бактерии да се прикрепят към лигавицата и да образуват както микроколонии от еднакви клетки, така и своеобразни съобщества с други микроорганизми. Биохимията на бактериалните клетки силно зависи от метода на култивиране - твърда среда или поточна култура. Твърде възможно е средното ухо, като специфична „инкубационна камера“, да е причина за особен биохимизъм и морфология на патогените, а не обратното. Независимо от първопричината, при фор- мирането на биофилм бактериалните клетки са слепени в полизахариден матрикс, който поради наличието на микропори запазва възможността за обмяна на микроорганизмите, като значително намалява възможността на макроорганизма да ликвидира инфекцията и вероятно блокира достъпа на антибактериални медикаменти. Пониженият биохимизъм на бактериите в микрофилма допълнително намалява ефективността на проникналите антимикробни субстанции, а близкият и продължителен контакт повишава възможността за генетичен обмен и се превръща в допълнителен източник на бактериална резистентност. Доказа се, че ниски антибиотични концентрации сами индуцират формирането на устойчив на тях биофилм (Ryan and Dow, 2008), като разликата в минималната антибиотична инхибираща концентрация за течна култура и за биофилм достига до 100 пъти.

\section{Генетика}

Съвременните методи за изследване с генни чипове, последвано от специализиран статистически анализ и справка с големите бази данни от геномното секвениране, откриват няколко кандидата за „рисков отитен“ ген (risk genes for otitis media). В мащабно популационно скриниране за „скаченост“ вероятна генна детерминираност се открива в зоните 10q22.3 и 17q12 (Casselbrant et al., 2009). В тази област са разположени генните детерминанти за белтьци с вече формулирана предполагаема роля за заболяването (АР2В1 adaptor-related protein complex 2 , beta 1 subunit; RANTES - еозинофилен хемоатрактант; SP-A - сьрфактантен протеин А). Все пак данните са твърде начални за категорично становище, а и в зоната на скаченост има локализирани редица други гени. Следва да се има предвид, че самите механизми на естествен, на вроден и на придобит имунитет са генетично детерминирани.

\section{Заключение}

При рецидивиращата форма на остьр среден отит проблемът следва да се търси в податливостта на организма към инфекция и евентуално в невъзможността му да изгради ефективна „имунологична памет“. При средния отит с излив проблемът е по-скоро в невъзможността на организма напълно да се освободи от инфекта и последиците на възпалението. Подобно разграничаване е важно за правилен подход 
към всеки конкретен случай, но често формите преминават една в друга и при липса на проследяване е трудно да се конкретизира какъв точно е проблемът във всеки един момент.

\section{Литература:}

1. Alho, O.P., Koivu, M., and Sorri, M. (1991). What is an „otitisprone“ child? Int. J. Pediatr. Otorhinolaryngol. 21, 201-209.

2. Bluestone, C.D. (2004). Definitions of otitis media and related diseases. In Advanced Therapy of Otitis Media, C.M. Alper, ed. (Hamilton, Ont.; Lewiston, NY: BC Decker), p.

3. Bluestone, C.D., and Klein, J.O. (2001). Otitis media in infants and children (Philadelphia: Saunders).

4. Casselbrant, M.L., Mandel, E.M., Jung, J., Ferrell, R.E., Tekely, K., Szatkiewicz, J.P., Ray, A., and Weeks, D.E. (2009). Otitis media: a genome-wide linkage scan with evidence of susceptibility loci within the $17 \mathrm{q} 12$ and $10 \mathrm{q} 22.3$ regions. BMC Medical Genetics 10,85 .

5. Faden, H., and Dryja, D. (1989). Recovery of a unique bacterial organism in human middle ear fluid and its possible role in chronic otitis media. J. Clin. Microbiol. 27, 2488-2491.

6. Fireman, B., Black, S.B., Shinefield, H.R., Lee, J., Lewis, E., and Ray, P. (2003). Impact of the pneumococcal conjugate vaccine on otitis media. Pediatr. Infect. Dis. J. 22, 10-16.

7. Harabuchi, Y., Faden, H., Yamanaka, N., Duffy, L., Wolf, J., and Krystofik, D. (1994a). Human milk secretory IgA antibody to nontypeable Haemophilus influenzae: possible protective effects against nasopharyngeal colonization. J. Pediatr. 124, 193-198.

8. Harabuchi, Y., Faden, H., Yamanaka, N., Duffy, L., Wolf, J., and Krystofik, D. (1994b). Nasopharyngeal colonization with nontypeable Haemophilus influenzae and recurrent otitis media. Tonawanda/Williamsville Pediatrics. J. Infect. Dis. 170, 862-866.

9. Harimaya, A., Takada, R., Himi, T., Yokota, S., and Fujii, N (2007). Evidence of local antibody response against Alloiococcus otitidis in the middle ear cavity of children with otitis media. FEMS Immunol. Med. Microbiol. 49, 41-45.

10. Howie, V.M., Ploussard, J.H., and Sloyer, J. (1975). The „otitisprone" condition. Am. J. Dis. Child. 129, 676-678.

11. Ichimiya, I., Kawauchi, H., and Mogi, G. (1990). Analysis of immunocompetent cells in the middle ear mucosa. Arch. Otolaryngol. Head Neck Surg. 116, 324-330.

12. Karchev, T., and Kabakchiev, P. (1984). M-cells in the epithelium of the nasopharyngeal tonsil. Rhinology 22, 201-210.

13. Konishi, M., Nishitani, C., Mitsuzawa, H., Shimizu, T., Sano, H Harimaya, A., Fujii, N., Himi, T., and Kuroki, Y. (2006). Alloiococ-
Авторът изказва благодарност на д-р Александър Райнов за критичния прочит и предложените корекции.

cus otitidis is a ligand for collectins and Toll-like receptor 2, and its phagocytosis is enhanced by collectins. Eur. J. Immunol. 36, $1527-1536$

14. Leibovitz, E., Greenberg, D., Piglansky, L., Raiz, S., Porat, N., Press, J., Leiberman, A., and Dagan, R. (2003). Recurrent acute otitis media occurring within one month from completion of antibiotic therapy: relationship to the original pathogen. Pediatr. Infect. Dis. J. 22, 209-216.

15. Leichtle, A., Hernandez, M., Pak, K., Webster, N.J., Wasserman, S.I., and Ryan, A.F. (2009). The toll-Like receptor adaptor TRIF contributes to otitis media pathogenesis and recovery. BMC Immunol. 10,45 .

16. Leskinen, K., Hendolin, P., Virolainen-Julkunen, A., Ylikoski, J., and Jero, J. (2004). Alloiococcus otitidis in acute otitis media. Int. J. Pediatr. Otorhinolaryngol. 68, 51-56.

17. Ovesen, T., Kragelund, J.R., Jensen, J.M., Thiel, S., and Veirum, J.E. (2011). Immunodeficiencies in children with chronic post tympanic otorrhoea. Dan Med Bull 58, A4282.

18. Paparella, M.M., Schachern, P.A., Yoon, T.H., Abdelhammid, M.M., Sahni, R., and da Costa, S.S. (1990). Otopathologic correlates of the continuum of otitis media. Ann Otol Rhinol Laryngol Suppl 148, 17-22.

19. Reinert, P. (1997). The role of pneumococcal and haemophilus type $B$ vaccination in the prevention of acute otitis media. Clin. Microbiol. Infect. 3 Suppl 3, S59-S61.

20. Rice, J.P., Saccone, N.L., and Rasmussen, E. (2001). Definition of the phenotype. Adv. Genet. 42, 69-76.

21. Ryan, R.P., and Dow, J.M. (2008). Diffusible signals and interspecies communication in bacteria. Microbiology (Reading, Engl.) 154, 1845-1858

22. Salazar, J.C., Daly, K.A., Giebink, G.S., Lindgren, B.R., Liebeler, C.L., Meland, M., and Le, C.T. (1997). Low cord blood pneumococcal immunoglobulin $\mathrm{G}$ (IgG) antibodies predict early onset acute otitis media in infancy. Am. J. Epidemiol. 145, 1048-1056.

23. Vitovski, S., Dunkin, K.T., Howard, A.J., and Sayers, J.R. (2002) Nontypeable Haemophilus influenzae in carriage and disease: a difference in IgA1 protease activity levels. Jama 287, 1699-1705.

24. (2004). Otitis media with effusion. Pediatrics 113, 1412-1429. 